\title{
Subcontractor Oversight on Construction Cost Overruns in Real Estate Projects in Nairobi and Kisumu Counties, Kenya
}

\author{
Joanne A. Kepher ${ }^{1}$, Charles M. Rambo ${ }^{1} \&$ Raphael O. Nyonje ${ }^{2}$ \\ ${ }^{1}$ Faculty of Business and Management Sciences, University of Nairobi, Kenya \\ ${ }^{2}$ Faculty of Education, University of Nairobi, Kenya \\ Correspondence: Joanne A. Kepher, Faculty of Business and Management Sciences, Department of Management \\ Sciences and Project Planning, University of Nairobi, Kenya, P.O.Box 2752-40100, Kisumu, Kenya. Tel: 254-7- \\ 2273-6776. E-mail: jkepher@yahoo.com
}

Received: September 21, 2021

Accepted: October 27, 2021

Online Published: October 28, 2021

doi:10.5539/jsd.v14n6p15

URL: https://doi.org/10.5539/jsd.v14n6p15

\begin{abstract}
Cost overruns have provided a significant challenge in the construction industries of both developed and developing countries. The purpose of this study was to investigate the influence Subcontractor Oversight on Construction Cost Overruns of real estate projects in Nairobi and Kisumu Counties. The study was guided by objective, to establish the extent to which subcontractor oversight influence real estate construction projects cost overruns. The research adopted descriptive survey and correlational research designs. The study targeted a population of 4000 project professionals that constituted 7 professionals from active real estates in Nairobi and Kisumu Counties and 10 key informants from the real estate industry. Using the Krejcie and Morgan table of sample size determination, the sample size for this study was 351. The study then adopted stratified, simple random and purposive sampling methods to select appropriate sample sizes from the study population strata. Structured questionnaire was the main instrument for data collection, supported by interview guide. Hypothesis was tested at $\alpha=0.05$ level of significance and the results were: $\mathrm{H} 0$ : There is no significant relationship between subcontractor oversight and real estate construction projects cost overruns was rejected since $\mathrm{P}=0.000<0.05$. Considering the study findings and conclusions, the following recommendations were made: Project professionals and other relevant real estate project stakeholders should encourage comprehensive subcontractor oversight as critical concerns in assembling pertinent information and creating avenues that could be utilized to reduce real estate construction projects cost overruns.
\end{abstract}

Keywords: cost overrun, construction projects, real estate, subcontractor oversight

\section{Introduction}

Cost overruns is a significant challenge in construction projects. The significance and linkage of construction industry to economic growth and development of all sectors in a country cannot be underrated ((Durdyev, Omarov, and Ismail, 2017). The constraints of cost, time and quality contribute to rating of projects' achievement with a concentration on cost constraint as a result of past performances of various studied projects. Overruns in cost and quality have attracted a wide range of research to an extent that it has become a global phenomenon and therefore proper reduction of construction cost is a recommendation by scholars as an aggregate for the successful completion of projects (Ahady, Gupta, and Malik, 2017). Reduction of construction cost overrun is key to project performance despite the fact that it has proved to be laborious in the construction industry (Alias, Zawawi, Yusof, and Aris, 2014).

Successful projects are supposedly the ones which meet the triple constraint standard where time, cost and quality are adequately achieved. Project success is subject to efficacy in management of the cost element. The main objective of project owners is to have their projects executed within their approved budgets and this leads them to engage professionals such as quantity surveyors to specifically manage financial aspects of the construction on their behalf; they consider cost certainty very highly. Cost overruns in construction projects is a familiar occurrence (Cunningham, 2017).

Subcontractor oversight can be equated to contract management which is always overlooked as part of procurement process. The Government of West Australia in their study (2019) "Planning for Contract Management" points out 
that all requirements in a contract must be outlined properly before embarking on a procurement process to guide all parties including the subcontractors on the scope of a project. It also stipulates the monitoring and evaluation processes in the contract. Simply put it guides all the parties in a contract arrangement to understand the yardstick used to measure performance in relation to a particular project (Government of Western Australia, 2019). Cooke and Williams (2004) and Dow, Sertyesilisik and Ross (2009) allude that contractors are mainly tasked with the responsibility to ensure that a project delivered in accordance to outlined specifications on a contract agreement.

\subsection{Research Objective}

The objective of the study was to assess how subcontractor Oversight influence real estate construction projects cost overruns.

\subsection{Research Hypothesis}

Ho: There is no significant relationship between subcontractor oversight and Real estate construction projects cost overruns.

\section{Literature Review}

\subsection{Real Estate Construction Projects Cost Overruns}

This study adopted the definition of Construction Cost Overruns as a structured multidisciplinary analysis of control process aiming to reduce excess of actual construction cost over budget in real estate projects (Khodeir and Ghandour, 2018). Construction Cost Overruns refer to processes that include accurate estimates, complete designs, correct scheduling, planning for scope changes and efficient administration. Different scholars have conducted studies to assess the causes of cost overruns in construction projects (Khodier and Ghandour, 2018; Niazi and Painting, 2017; Lind and Brunes, 2015; Doloi, 2013 and Rosenfed, 2013).

Out of the studies that were reviewed; Lind and Brunes (2015) and Khodeir and Ghandour, (2018) focused on the importance of competence, skills and value management in the management of cost overruns, Doloi (2013) on the other hand focused on the responsibilities of key stakeholders including clients, consultants, and contractors. On the other hand, Niazi and Painting (2017) established that cost overruns were caused by: corruption; delays in progress payment by clients; difficulties by contractors to financing projects; insecurity; decision by the owners to change order during construction; documentation; price increases; and manner of contract award. Also, Rosenfed (2013) found that premature tender documents, numerous changes in the owners' requirements and unrealistically low tender-winning prices caused construction cost overrun.

Construction Cost Overruns in this study was viewed from the perspective of: accurate project estimates; correct plan; complete project designs; planning for changes in project scope; and efficient administration of projects. Studies by (Khodier and Ghandour, 2018; Niazi and Painting, 2017; Lind and Brunes, 2015; Doloi, 2013 and Rosenfed, 2013) had concurrence with this study. This study focus was that low priced projects cost more than expected at the end, project costs are controlled through accepting minimal claims during implementation, strict adherence to comprehensive designs at tendering stage minimize project claim, whenever there is proper coordination at the design level unexpected outcomes during implementation are minimized, escalations are experienced due to errors in project activity scheduling, incorporating scheduling techniques help to save project cost, planning for scope changes is a requisite to minimize project cost, regulation of project cost becomes harder due to wrong initial scope definition, proper coordination of projects minimize project cost and that precisely organized project activities ensure control of un-anticipated expenses. Therefore, this study established the key indicators of reduction of cost overruns on real estate projects in Kenya's Nairobi and Kisumu Counties.

\subsection{Sub-Contractor Oversight and Real Estate Construction Projects Cost Overruns}

Hewavitharana and Perera (2019) conducted a mixed method study titled "Gap Analysis between ERP procedures and Construction procedures" on a sample of 210 participants in Sri Lanka. The study concluded that a significant gap existed between construction procedures and ERP procedures in all fields related to the construction industry. Therefore, Subcontractor oversight which had the lowest gap of 0.492 could be aligned to the main objective of the study which was to develop a framework which meets organizational procedures and ERP procedures after identifying the conflicting areas that create the gap between ERP procedures and construction practices. For Subcontractor oversight, the low gap could be attributed to: biased ways of selecting subcontractors; lack of tracking the work done; mixing up subcontractor type and ad-hoc practices in subcontractor payment; manipulating working progress according to the Bill of Quantities; analyzing variation and initiating the required method to handle; and producing a systematic way of payment respectively, (Hewavitharana and Perera, .2019). Nonparametric tests are not robust enough and therefore the results of this study might not be strong. The current study a parametric tests towards ensuring that the results are rigorous enough. 
The fact that supervisor support can influence management of cost overruns in project network management has also been established. A survey was conducted by Hwang and $\mathrm{Ng}$ (2013) to investigate the current status of network management and to identify the network risks most widely faced by the construction industry in Singapore. The researchers sought to: explore the attitudes and understanding of project network management; identify critical risks affecting the construction project network; and determine stakeholders who most contribute to these risks. Hwang and $\mathrm{Ng}$ (2013) posited that effective project risk management can be carried out by gaining an understanding of relationships among the various stakeholders in the project network as well as the critical risks related to the network structure, which would ultimately increasing the probability of project success. The study was conducted among contractors and subcontractors to establish how the two parties contribute to the project network and the how the different types of network risks were perceived by the parties. Findings indicated that the designers, subcontractors and project managers were the parties with whom the respondents communicated with constantly within the project network to ensure the smooth delivery of the end product.

Work related crime is a major challenge facing the construction industry in Norway. With regard to this, Evjen, Gunnerud, Lædre, Søfting and Lohne (2019) conducted a study to assess the perception of subcontractors on workrelated crime within the industry. Initially, Arksey and O'Malley (2005) suggestions on literature review was followed focusing on "the current state of the AEC industry", "work-related crime" and "control system of subcontractors in Norway". Interview guide was used to obtain response from companies with different projects. It was therefore established that available controls had gaps that allowed work related criminal activities to continue. Evjen, et al. (2019) cited the main problems as: warnings; procurement and bureaucratic process which were a hindrance to effective control of subcontractors. Reduced number of reporting authorities or tiers was suggested as one measure of controlling criminal activities.

Inaccuracies in estimating the costs and quantities of materials need in a project can impact on the project by resulting in cost overruns. This was revealed by Baloyi and Bekker (2011) in their qualitative study conducted on a sample size of 60 respondents in South Africa to determine the cause of construction cost and time overruns in the 2010 FIFA World Cup stadia. A total of 10 stadia in South Africa was to be prepared for the great event either through new construction or renovation. The response rate for this study stood at 36 percent. However, this response rate was too low making it difficult to conclude statistically significant findings. The researchers found that increase in the cost of material was the most significant contributor to the cost overruns because of inaccuracies of making material estimates in the bills of quantities. However, due to its qualitative nature, this study ran short of establishing the magnitude of the overruns that are caused by the inaccuracies in material estimations. It is therefore important to conduct a quantitative study to establish the numerical magnitude of such inaccuracies in a project, ((Baloyi and Bekker, 2011).

Procurement procedures are important components in the management of cost overruns in projects. In line with this, Omemo and Sang (2018) conducted a descriptive study to ascertain the how performance of constituency development fund (CDF) funded construction projects in Migori East, Kenya was influenced by procurement procedures. The study which had a sample size of 62 respondents highlighted the important role that procurement procedures including specification definition, bid invitation and bid evaluation play in ensuring proper implementation of projects. It noted that it is important to distinguish between the activities to be implemented by the organization and those to be outsourced. The study concluded that the efficiency of any development enterprise can be enhanced through the improvement of procurement processes, (Omemo and Sang, 2018). However, the researchers used descriptive design in the study which assessed cause/effect.

Contract negotiation processes and the ethical considerations accompanying them are crucial project components that might be overlooked in some projects. In view of this, Mwenda, Otieno-Omutoko, and Gakuu (2018) conducted a mixed method study to determine how ethical concerns in project contract negotiation influenced the quality of building construction projects in Nairobi County. Descriptive survey and correlational research designs were used in the study on a sample of 192 respondents. The study concluded that ethical concerns did not influence contract negotiation in the quality of residential buildings construction projects.

The study focused on proper selection of subcontractor as vital, subcontractor capacity is a point of primary focus, engagement of comprehensive negotiation with subcontractor is key, conflict and misunderstanding with subcontractor should be minimized, proper assignment of subcontractor activities is necessary, adequate facilitation to integrate a subcontractor in project activities should be considered, continuous tracking of subcontractor progress should be guaranteed, proper tools to track subcontractor activities should be used, right procedures to close subcontractor work is crucial, and that observation of legal compliance in subcontractor termination is crucial hence all these constructs positively influence Real estate construction projects cost overruns in Kenya's Nairobi and Kisumu Counties. 


\subsection{Theoretical Framework}

This study was guided by the Microeconomic Production Theory current by Lerner (1968) and focused on the concept of cost function in that theory. This is a build-up of the works of Cantarelli et al. (2010), and adopted from Lind and Brunes (2015). The study focused its attention to the components of: Forecasting theory and Machiavellianism theory. These works on explaining the cost overruns in infrastructure projects since real estate projects are part of infrastructure projects. The theory studied the behaviour of individual firms in regards to fixation of price and output and their reaction to the changes in the demand and supply conditions; thus it seeks to determine the mechanism by which the different economic units attain the position of equilibrium proceeding from individual units to an industry or a market: in our case being the construction industry and specifically real estate projects.

\subsection{Conceptual Framework}

This study has adopted a conceptual framework outlined in figure 1 indicating the relationship of the independent variable and dependent variable.

Independent variable Financing and Contract Management

Dependent variable

Subcontractor Oversight

- Selection of Subcontractor

- Negotiation with Subcontractor

- Assigning Subcontractor Activities

- Tracking Subcontractor Progress

- Subcontractor Work Closing

Figure 1. Conceptual framework for subcontractor oversight on construction cost overruns in real estate project

\section{Research Methodology}

This study used a descriptive survey research design and specifically; cross sectional survey as well as correlational design. The descriptive design used in this study helped to explore the link between the variables (Brook, 2013). Target population was based on the register of real estate projects between 2018 and 2019 held by the National construction Authority (NCA) which had 570 active real estate projects comprising of 95 in Kisumu and 475 in Nairobi Counties. In general, a typical real estate project structure comprises Project professionals such as Construction manager, clerk of works, Quantity Surveyor, Architect, Mechanical and Electrical engineer, structural Engineer, Contractor and Subcontractors. The 570 active real estate projects in Kisumu and Nairobi Counties each have at least one of the project professional. Thus a minimum of 7 project professional per real estate project constituted a target population of $4000=(570 \times 7)$ project professional as well as 10 key informants.

A sample size of 351 was drawn from a target population of 4000 project professional and key informants in Nairobi and Kisumu Counties. The sample size for the study was determined using Krejcie and Morgan table (Krejcie and Morgan, 1970). Based on the table, for a given population of 4000, a sample size of 351 was obtained and was further confirmed through hyper-geometric formula for a sample size as follows;

$$
\mathrm{n}=\frac{Z^{2} \quad N \cdot P \cdot(1-P)}{e^{2}(N-1)+Z^{2} P(1-P)}
$$

Proportionate stratified and simple random sampling technique was used to select sample sizes from different strata (project professionals) out of the 570 active real estate projects registered and operating in Nairobi and Kisumu Counties; Purposive sampling was used to select key informants from a targeted population of ten having prerequisite experience in real estate development. Data for this study was collected in phases; pre-field work phase, field work phase and post-field work phase. The data collection was done by using survey questionnaire and interview guide. 


\section{Results and Discussions}

\subsection{Questionnaire Return Rate}

Out of the sample size of 351 from the target population, 8 key informants were interviewed whereas 343 participants from the seven active real estates licensed to operate within Kisumu and Nairobi Counties by National Construction Authority were issued with questionnaires of which 336 dully filled and returned the questionnaires giving a return rate of $98 \%$. Table 1 shows the Questionnaire Return Rate for the Project professionals from the seven active real estates licensed to operate within Kisumu and Nairobi Counties by National Construction Authority that were responded to and returned.

Table 1. Questionnaire return rate

\begin{tabular}{lllc}
\hline County & Sampled & Returned & Return Rate\% \\
\hline Nairobi & 287 & 281 & 81.92 \\
Kisumu & 56 & 55 & 16.04 \\
Total & $\mathbf{3 4 3}$ & $\mathbf{3 3 6}$ & $\mathbf{9 7 . 9 6}$ \\
\hline
\end{tabular}

The high return rate was attained because the researcher consistently followed up all the sampled respondents during data collection. The high return rate of $98 \%$ facilitated gathering of sufficient data that could be generalized to determine the influence of Financial and Contract Management on Real estate construction projects cost overruns in Kisumu and Nairobi Counties. The Questionnaire return rate was considered adequate as per Mugenda and Mugenda (2003) and Kothari (2004) who recommended that a Questionnaire return rate beyond 50\% is acceptable in research and subsequently satisfactory and contributes towards gathering of sufficient data that could be generalized to represent the opinions of participants.

\subsection{Demographic Characteristics of the Respondents}

In order to understand the characteristics of participants the researcher was dealing with in the study, their background information was necessary. The study sought information from the participants on distribution by, position category in real estate projects, duration of profession in the organization and kind of construction projects conducted in real estate projects. The participants were asked to provide these demographic information.

\subsubsection{Distribution of Respondents by Position Category}

It was imperative to investigate the respondents' position category to establish how financial and contract management of real estate projects were related with cadre of the project professional whose information were considered to be significance to the construction agencies for policy decision making. The respondents were therefore asked to state their position category and the results are presented in Table 2.

Table 2. Distribution of respondents by position category

\begin{tabular}{lllll}
\hline Position category & Frequency & Cumulative frequency & Valid Percent & Cumulative percentage \\
\hline Quantity Surveyor & 41 & 41 & 12.20 & 12.20 \\
Construction Manager/Clerk of works & 66 & 107 & 19.60 & 31.80 \\
Structural Engineer & 49 & 156 & 14.60 & 46.40 \\
Contractor & 81 & 237 & 24.10 & 70.50 \\
Architect & 35 & 272 & 10.40 & 80.90 \\
Mechanical and Electrical Engineer & 40 & 312 & 11.90 & 92.80 \\
Other Staff & 24 & 336 & 7.20 & 100 \\
\hline Total & $\mathbf{3 3 6}$ & & $\mathbf{1 0 0 . 0 0}$ & \\
\hline
\end{tabular}

Table 2 , shows that $81(24.10 \%)$ were categorized as contractor project professionals, $66(19.60 \%)$ were categorized as Construction Manager/Clerk of work project professionals, 49(14.6\%) were categorized as structural Engineers project professionals, $40(11.9 \%)$ were categorized as Mechanical and Electrical Engineer project 
professionals, $41(12.2 \%)$ were categorized as quantity surveyors , $35(10.4 \%)$ were categorized as architects project professionals project professionals and $24(7.2 \%)$ were categorized as other staff by project professionals. The findings on position category indicates that real estate projects are undertaken by qualified project professionals capable of responding to information sought on financial and contract management, project environment, organization capacity and real estate construction projects cost overruns. Doloi (2012) established that position category by project professional is a contributing factor on the relationship between financial contract management and real estate construction projects cost overruns.

\subsection{Basic Tests for Statistical Assumptions of Regression Analysis}

The study was based on a set of assumptions of regression analysis that must be met to ensure the data collected is appropriate for the statistical analysis. When these assumptions are violated the results of the analysis can be erroneous. The assumptions tested include normality, linearity, multi-collinearity and independence of errors.

\section{Assumptions of Normality}

An assessment of the normality of data is a prerequisite for many statistical tests because normal data is an underlying assumption in parametric testing. The test for normality of data distribution was conducted on all the predictor variables, moderating variables using Kolmogorov-Smirnov test statistics (KS-test) and Shapiro-Wilk test (SW-test).

\subsection{Subcontractor Oversight and Real Estate Construction Projects Cost Overruns}

Subcontractor Oversight in this study is defined as the process that involves procurement, negotiation, on-boarding, exit and end of contract review. This was the second objective that the study sought to achieve; therefore, the participants were requested to give their opinions on their level of agreements or disagreements with the ten statements of Subcontractor Oversight on a Likert scale of $1-5$ where Strongly agree $(\mathrm{SA})=5$, Agree $(\mathrm{A})=4$ $\operatorname{Neutral}(\mathrm{N})=3$, Disagree $(\mathrm{D})=2$ and Strongly disagree. $(\mathrm{SD})=1$. The results were analyzed and presented using frequencies, percentage, means and standard deviations for each response in each item. The item mean as well as the standard deviation were also computed and presented alongside as provided in Table 3 .

Table 3. Subcontractor oversight and real estate construction projects cost overruns

\begin{tabular}{|c|c|c|c|c|c|c|c|}
\hline STATEMENTS & SA & $\mathbf{A}$ & $\mathbf{N}$ & D & SD & Mean & $\begin{array}{l}\text { Std. } \\
\text { dev }\end{array}$ \\
\hline 1. Proper selection of subcontractor is vital & $223(66.3 \%)$ & $92(27.4 \%)$ & $18(5.4 \%)$ & $3(0.9 \%)$ & $0(0.00 \%)$ & 4.59 & 0.635 \\
\hline $\begin{array}{l}\text { 2. Subcontractor capacity is a point of primary } \\
\text { focus }\end{array}$ & $155(46.1 \%)$ & $131(39.0 \%)$ & $41(12.2 \%)$ & $9(2.7 \%)$ & $0(0.00 \%)$ & 4.29 & 0.781 \\
\hline $\begin{array}{l}\text { 3. Engagement of comprehensive negotiation } \\
\text { with subcontractor is key }\end{array}$ & $148(44 \%)$ & $134(39.9 \%)$ & $39(11.6 \%)$ & $15(4.5 \%)$ & $0(0.00 \%)$ & 4.24 & 0.826 \\
\hline $\begin{array}{l}\text { 4. Conflict and misunderstanding with } \\
\text { subcontractor should be minimized }\end{array}$ & $149(44.3 \%)$ & $158(47.1 \%)$ & $26(7.7 \%)$ & $3(0.9 \%)$ & $0(0.00 \%)$ & 4.35 & 0.661 \\
\hline $\begin{array}{l}\text { 5. Proper assignment of subcontractor activities } \\
\text { is necessary }\end{array}$ & $149(44.3 \%)$ & $155(46.2 \%)$ & $26(7.7 \%)$ & $6(1.8 \%)$ & $0(0.00 \%)$ & 4.33 & 0.696 \\
\hline $\begin{array}{l}\text { 6. Adequate facilitation to integrate a } \\
\text { subcontractor in project activities should be } \\
\text { considered }\end{array}$ & $146(43.5 \%)$ & $167(49.7 \%)$ & $22(6.5 \%)$ & $1(0.3 \%)$ & $0(0.00 \%)$ & 4.36 & 0.617 \\
\hline $\begin{array}{l}\text { 7. Continuous tracking of subcontractor progress } \\
\text { should be guaranteed }\end{array}$ & $136(40.5 \%)$ & $172(51.2 \%)$ & $25(7.4 \%)$ & $3(0.9 \%)$ & $0(0.00 \%)$ & 4.31 & 0.647 \\
\hline $\begin{array}{l}\text { 8. Proper tools to track subcontractor activities } \\
\text { should be used }\end{array}$ & $144(42.9 \%)$ & $148(44.0 \%)$ & $40(11.9 \%)$ & $4(1.2 \%)$ & $0(0.00 \%)$ & 4.29 & 0.718 \\
\hline $\begin{array}{l}\text { 9. Right procedures to close subcontractor work } \\
\text { is crucial }\end{array}$ & $139(41.4 \%)$ & $163(48.5 \%)$ & $31(9.2 \%)$ & $3(0.9 \%)$ & $0(0.00 \%)$ & 4.30 & 0.671 \\
\hline $\begin{array}{l}\text { 10. Observation of legal compliance in } \\
\text { subcontractor termination is crucial }\end{array}$ & $206(61.3 \%)$ & $121(36 \%)$ & $8(2.4 \%)$ & $1(0.3 \%)$ & $0(0.00 \%)$ & 4.58 & 0.556 \\
\hline \multicolumn{6}{|l|}{ Composite mean \& Composite standard deviation } & 4.36 & 0.686 \\
\hline
\end{tabular}


The results in Table 3 indicates that the composite mean and composite deviation for the Subcontractor oversight were 4.36 and 0.686 respectively; implying that using the Likert scale a majority at least agreed $(m e a n=4.36)$ that Subcontractor oversight influences Real estate construction projects cost overruns. Similarly ten statements were developed to measure the extent to which Subcontractor oversight influences Real estate construction projects cost overruns.

Statement (1) that 'Proper selection of subcontractor is vital' had a mean of 4.59 and a standard deviation of 0.635. This results indicate that out of 336 study participants, 223(64.3\%) strongly agreed, 92(27.4\%) agreed, 18(5.4\%) were neutral and $3(0.9 \%)$ disagreed that proper selection of subcontractor is vital. This results shows that the line statement mean score of 4.59 was higher than the composite mean of 4.36. The implication of this result to the study is that proper selection of subcontractor is vital and hence positively influence management of Real estate construction projects cost overruns. The lower line item standard deviation of 0.635 than the composite standard deviation of 0.686 indicate that there was a convergence view in opinion among the study participants that proper selection of subcontractor is vital in reduction of Real estate construction projects cost overruns. The study results support findings by Enshassi, Arain and Tayeh (2012) who found out that proper selection of subcontractor is vital in reduction of Real estate construction projects cost overruns.

Statement (2) that 'Subcontractor capacity is a point of primary focus' had a mean of 4.29 and a standard deviation of 0.781 . This results indicate that out of 336 study participants, $155(46.1 \%)$ strongly agreed, 131(39.0\%) agreed, $41(12.2 \%)$ were neutral and $9(2.7 \%)$ disagreed that subcontractor capacity is a point of primary focus. This results shows that the line statement mean score of 4.29 was lower than the composite mean of 4.36 . The implication of this result to the study is that there is need to focus primarily on subcontractor capacity in order to positively influence management of Real estate construction projects cost overruns. The higher line item standard deviation of 0.781 than the composite standard deviation of 0.686 indicate that there was a divergence view in opinion among the study participants. The study results support findings by Chen, Ding, Cory, Hu, Wu and Feng (2019) who found out that subcontractor capacity is a point of primary in reduction of Real estate construction projects cost overruns.

Statement (3) that 'Engagement of comprehensive negotiation with subcontractor is key' had a mean of 4.24 and a standard deviation of 0.826 . This results indicate that out of 336 study participants, 148(44\%) strongly agreed, $134(56 \%)$ agreed, $39(16.1 \%)$ were neutral and $15(4.5 \%)$ disagreed that engagement of comprehensive negotiation with subcontractor is key. This results shows that the line statement mean score of 4.24 was lower than the composite mean of 4.36. The implication of this result to the study is that there is need for engagement of comprehensive negotiation with subcontractor in order to positively influence management of Real estate construction projects cost overruns. The higher line item standard deviation of 0.826 than the composite standard deviation of 0.686 indicate that there was a divergence view in opinion among the study participants. The study results support findings by Stevens, Frame and Henjewele (2015) who found out that engagement of comprehensive negotiation with subcontractor is key in reduction of Real estate construction projects cost overruns.

Statement (4) that 'Conflict and misunderstanding with subcontractor should be minimized' had a mean of 4.35 and a standard deviation of 0.661 . This results indicate that out of 336 study participants, $149(44.3 \%)$ strongly agreed, 158(47.1\%) agreed, 26(7.7\%) were neutral and 3(0.9\%) disagreed that conflict and misunderstanding with subcontractor should be minimized. This results shows that the line statement mean score of 4.35 was lower than the composite mean of 4.36. The implication of this result to the study is that there is need minimize conflict and misunderstanding with subcontractor in order to positively influence management of Real estate construction projects cost overruns. The lower line item standard deviation of 0.661 than the composite standard deviation of 0.686 indicate that there was a convergence view in opinion among the study participants. The study results support findings by Enshassi, Arain and Tayeh (2012) who found out that minimization of conflict and misunderstanding with subcontractor enhances reduction of Real estate construction projects cost overruns.

Statement (5) that 'Proper assignment of subcontractor activities is necessary' had a mean of 4.33 and a standard deviation of 0.696 . This results indicate that out of 336 study participants, $149(44.3 \%)$ strongly agreed, $155(46.2 \%)$ agreed, 26(7.7\%) were neutral and 6(1.8\%) disagreed that proper assignment of subcontractor activities is necessary. This results shows that the line statement mean score of 4.33 was lower than the composite mean of 4.36. The implication of this result to the study is that there is need for proper assignment of subcontractor activities in order to positively influence management of Real estate construction projects cost overruns. The higher line item standard deviation of 0.696 than the composite standard deviation of 0.686 indicate that there was a divergence view in opinion among the study participants. The study results support findings by Loosemore (2013) who found out that proper assignment of subcontractor activities reduces Real estate construction projects cost overruns. 
Statement (6) that 'Adequate facilitation to integrate a subcontractor in project activities should be considered' had a mean of 4.36 and a standard deviation of 0.617 . This results indicate that out of 336 study participants, $146(43.5 \%)$ strongly agreed, $167(49.7 \%)$ agreed, $22(6.5 \%)$ were neutral and $1(0.3 \%)$ disagreed that adequate facilitation to integrate a subcontractor in project activities should be considered. This results shows that the line statement mean score of 4.36 was the same as the composite mean of 4.36 . The implication of this result to the study is that adequate facilitation to integrate a subcontractor in project activities should be considered since it positively influence management of Real estate construction projects cost overruns. The lower line item standard deviation of 0.617 than the composite standard deviation of 0.686 indicate that there was a convergence view in opinion among the study participants. The study results support findings by Eriksson, Dickinson and Khalfan (2007) who found out that consideration of adequate facilitation to integrate a subcontractor in project activities reduces Real estate construction projects cost overruns.

Statement (7) that 'Continuous tracking of subcontractor progress should be guaranteed' had a mean of 4.31 and a standard deviation of 0.647 . This results indicate that out of 336 study participants, $136(40.5 \%)$ strongly agreed, $172(51.2 \%)$ agreed, $25(7.4 \%)$ were neutral and $3(0.9 \%)$ disagreed that continuous tracking of subcontractor progress should be guaranteed. This results shows that the line statement mean score of 4.31 was the lower than the composite mean of 4.36. The implication of this result to the study is that there is need to continuously track subcontractor progress in order to positively influence management of Real estate construction projects cost overruns. The lower line item standard deviation of 0.647 than the composite standard deviation of 0.686 indicate that there was a convergence view in opinion among the study participants. The study results supports finding by Sarshar, Haigh and Amaratunga (2004) who found out that consideration of continuous tracking of subcontractor progress should be guaranteed to enable reduction of Real estate construction projects cost overruns.

Statement (8) that 'Proper tools to track subcontractor activities should be used' had a mean of 4.29 and a standard deviation of 0.718 . This results indicate that out of 336 study participants, $144(42.9 \%)$ strongly agreed, $148(44.0 \%)$ agreed, $40(11.9 \%)$ were neutral and $4(1.2 \%)$ disagreed that proper tools to track subcontractor activities should be used. This results shows that the line statement mean score of 4.29 was the lower than the composite mean of 4.36. The implication of this result to the study is that there is need to effectively put to use proper tools to track subcontractor activities in order to positively influence management of Real estate construction projects cost overruns. The higher line item standard deviation of 0.718 than the composite standard deviation of 0.686 indicate that there was a divergence view in opinion among the study participants. The study results supports finding by Havenvid, Holmen, Linne and Pedersen (2016) who found out that using proper tools to track subcontractor activities enhance reduction of Real estate construction projects cost overruns.

Statement (9) that 'Right procedures to close subcontractor work is crucial' had a mean of 4.30 and a standard deviation of 0.671 . This results indicate that out of 336 study participants, $139(41.4 \%)$ strongly agreed, $163(48.5 \%)$ agreed, $31(9.2 \%)$ were neutral and $3(0.9 \%)$ disagreed that right procedures to close subcontractor work is crucial. This results shows that the line statement mean score of 4.30 was the lower than the composite mean of 4.36 . The implication of this result to the study is that there is need to adhere to right procedures to close subcontractor work in order to positively influence management of Real estate construction projects cost overruns. The lower line item standard deviation of 0.671 than the composite standard deviation of 0.686 indicate that there was a convergence view in opinion among the study participants. The study results supports finding by Jalali, Hidzir, Jaafar and Dahalan (2019) who found out that adherence to right procedures to close subcontractor work enables reduction of Real estate construction projects cost overruns.

Statement (10) that 'Observation of legal compliance in subcontractor termination is crucial' had a mean of 4.58 and a standard deviation of 0.556 . This results indicate that out of 336 study participants, $206(61.3 \%)$ strongly agreed, $121(36 \%)$ agreed, $8(2.4 \%)$ were neutral and $1(0.3 \%)$ disagreed that observation of legal compliance in subcontractor termination is crucial. This results shows that the line statement mean score of 4.58 was the higher than the composite mean of 4.36. The implication of this result to the study is that observation of legal compliance in subcontractor termination positively influence management of Real estate construction projects cost overruns. The lower line item standard deviation of 0.556 than the composite standard deviation of 0.686 indicate that there was a convergence view in opinion among the study participants. The study results supports finding by Zhang, Chen and $\mathrm{Lu}$ (2021) who found out that observation of legal compliance in subcontractor termination is crucial in reducing Real estate construction projects cost overruns.

\subsection{Correlation Analysis of Subcontractor Oversight and Real Estate Construction Projects Cost Overruns}

The study sought to examine the relationship between Subcontractor oversight and real estate construction projects cost overruns. Pearson correlation coefficient was used to test the relationship between Subcontractor oversight 
and real estate construction projects cost overruns at $95 \%$ level of confidence. The correlations results obtained are shown in Table 4.

Table 4. Correlations of subcontractor oversight and real estate construction projects cost overruns

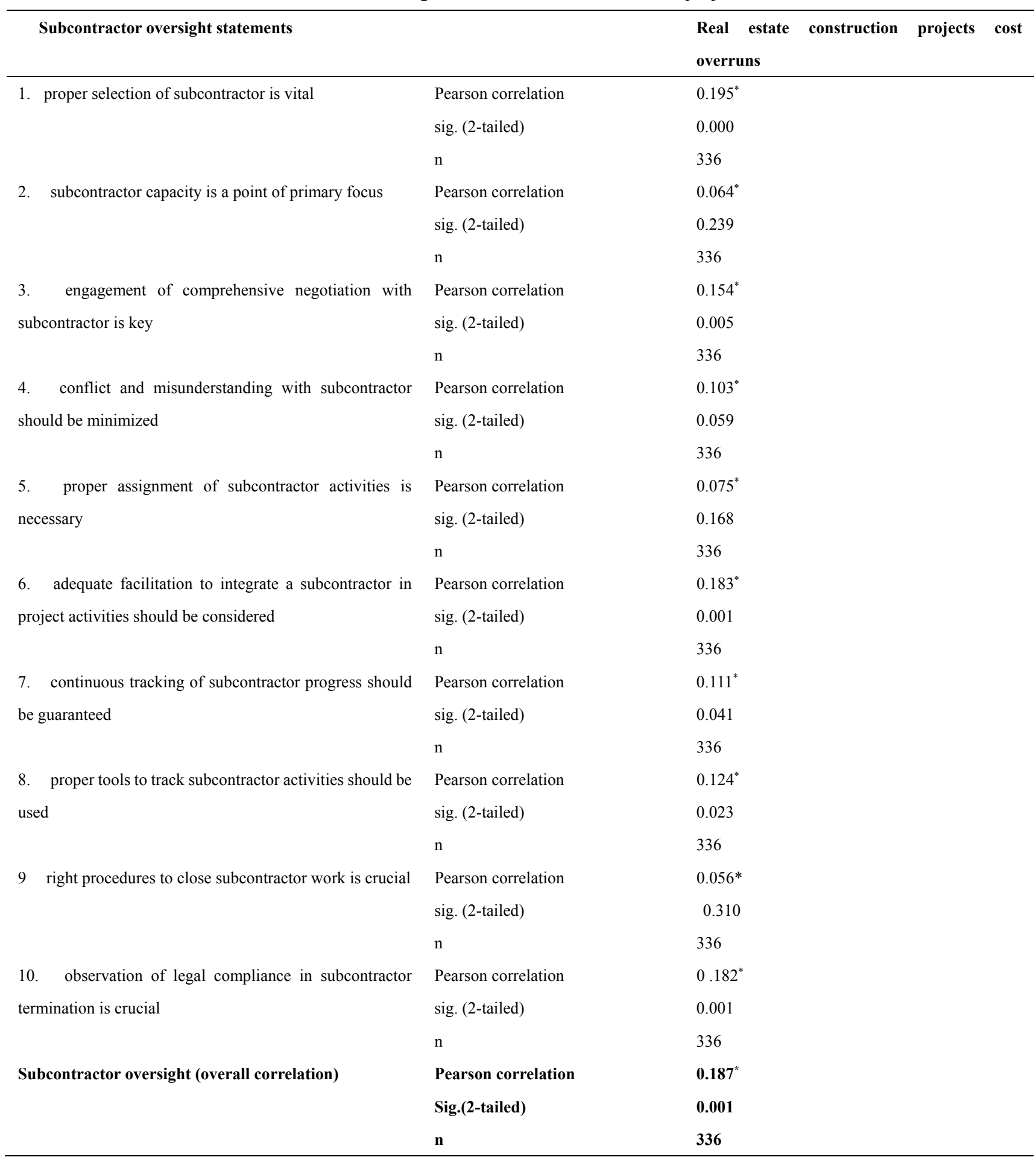

\footnotetext{
*Correlation is significant at 0.05 level (2-tailed)
}

To test the extent of the relationship between Subcontractor oversight and real estate construction projects cost overruns; several characteristics of Subcontractor oversight and real estate construction projects cost overruns were analyzed based on the following hypothesis; $\mathrm{H}_{0}$ : There is no significant relationship between Subcontractor 
oversight and real estate construction projects cost overruns. The corresponding mathematical model for the hypothesis was identified as follows: real estate construction projects cost overruns $=f$ (Subcontractor oversight). The correlation results presented in Table 4.16 indicated that six out of the ten statements under significant 2-tailed were found to be significant since the P-values $<0.05$ whereas four statement were not significant since their $\mathrm{p}$ values $>0.05$; ( Statement 1; proper selection of subcontractor is vital $; \mathrm{r}=0.195$, P-value $=0.000<0.05$,Statement 2; subcontractor capacity is a point of primary focus; $r=0.064$, P-value $=0.239>0.05$, Statement 3 ; engagement of comprehensive negotiation with subcontractor is key; $\mathrm{r}=0.154$, P-value $=0.005<0.05$,Statement 4 ; conflict and misunderstanding with subcontractor should be minimized ; $\mathrm{r}=0.103$, P-value $=0.059>0.05$, Statement 5; proper assignment of subcontractor activities is necessary .; $\mathrm{r}=0.075$, P-value $=0.168>0.05$, Statement 6; adequate facilitation to integrate a subcontractor in project activities should be considered $; \mathrm{r}=0.183$, $\mathrm{P}$-value $=0.001<0.05$, Statement 7; continuous tracking of subcontractor progress should be guaranteed; $\mathrm{r}=0.111$, Pvalue $=0.041<0.05$, Statement 8 ; proper tools to track subcontractor activities should be used $; \mathrm{r}=0.124$, $\mathrm{P}$ value $=0.023<0.05$, Statement 9; right procedures to close subcontractor work is crucial; $r=0.056$, $P$ value $=0.310>0.05$ and Statement 10; observation of legal compliance in subcontractor termination is crucial; $\mathrm{r}=0.182$, $\mathrm{P}$-value $=0.001<0.05$ ).

In order to determine the correlation between Subcontractor oversight and construction cost overruns, Pearson correlation coefficient was run on the scores of each scale. The total scores of the scales were computed as a summation of the individual scores on each item by the respondent at $95 \%$ level of confidence. The study found a positive overall correlation( $(\mathrm{r}=0.187)$ which was statistically significant as $\mathrm{P}<0.05(\mathrm{p}=0.001)$ between Subcontractor oversight and real estate construction projects cost overruns, implying that there is a significant relationship between Subcontractor oversight and real estate construction projects cost overruns leading to rejection of the null hypothesis $\left(\mathrm{H}_{0}\right.$ : There is no significant relationship Subcontractor oversight and real estate construction projects cost overruns) and acceptance of the alternative hypothesis, and hence the research findings conclude that there is a significant relationship between Subcontractor oversight and real estate construction projects cost overruns. This finding is in agreement with findings Ershadi, Jefferies, Davis and Mojtahedi (2020) study that found out that that there is a significant relationship between Subcontractor oversight and real estate construction projects cost overruns.

\subsection{Regression Analysis of Subcontractor Oversight on Real Estate Construction Projects Cost Overruns}

Simple linear regression was adopted to investigate how Subcontractor oversight influence real estate construction projects cost overruns. It was necessary to get the views of the participants on the influence of Subcontractor oversight on real estate construction projects cost overruns. The rational of using the simple regression model was to establish how Subcontractor oversight as a predictor significantly or insignificantly predicted the real estate construction projects cost overruns.

\subsubsection{Model Summary of Subcontractor Oversight on Real Estate Construction Projects Cost Overruns}

The model summary sought to determine how Subcontractor oversight is a predictor that significantly or insignificantly predicted real estate construction projects cost overruns. The regression model summary results are presented in Table 5.

Table 5. Regression model summary table of subcontractor oversight and real estate construction projects cost overruns

\begin{tabular}{lllll}
\hline \multicolumn{2}{l}{ Model Summary } & & & \\
\hline Model & $\mathrm{R}$ & R Square & Adjusted R Square & Std. Error of the Estimate \\
\hline 1 & $0.187 \mathrm{a}$ & 0.035 & 0.032 & 3.59205 \\
\hline
\end{tabular}

a. Predictors: (Constant), Subcontractor oversight

The model summary Table 5 suggest that there is a positive correlation $(\mathrm{R}=0.187)$ between Subcontractor oversight and real estate construction projects cost overruns and those predicted by the regression model. In addition, 3.5\% of the variation in the real estate construction projects cost overruns is explained by Subcontractor oversight. The results are consistent with the findings of a study by Ershadi, Jefferies, Davis and Mojtahedi (2020) who found out that there a positive correlation between Subcontractor oversight and construction cost overruns in projects. 


\subsubsection{ANOVA of Subcontractor Oversight and Real Estate Construction Projects Cost Overruns}

The study sought to establish if the regression model is best fit for predicting real estate construction projects cost overruns after use of Subcontractor oversight. The ANOVA results are presented in Table 6.

Table 6. An ANOVA of the regression of subcontractor oversight and real estate construction projects cost overruns

\begin{tabular}{llllll}
\hline Model & Sum of Squares & df & Mean Square & F & Sig. \\
\hline $1 \quad$ Regression & 156.452 & 1 & 156.452 & 12.125 & $0.001^{\mathrm{b}}$ \\
Residual & 4309.536 & 334 & 12.903 & & \\
Total & 4465.988 & 335 & & & \\
\hline
\end{tabular}

a. Dependent Variable: real estate construction projects cost overruns

b. Predictors: (Constant), Subcontractor oversight

The ANOVA results from Table 6 indicated that (F-statistics $(1,334)=12.125$ is significant since the $\mathrm{P}$-value $0.000<0.05$ implying that the predictor co-efficient is at least not equal to zero. and hence the regression model results in significantly better prediction of real estate construction projects cost overruns. The results are consistent with the findings of a study by Enshassi, Arain and Tayeh (2012) who found out that subcontractor oversight significantly predict better Real estate construction projects cost overruns.

4.6.3 Coefficients for Regression of Subcontractor Oversight and Real Estate Construction Projects Cost Overruns

The study sought to establish whether there was influence of Subcontractor oversight and Real estate construction projects cost overruns. The regression coefficients results are presented in Table 7.

Table 7. Coefficients for the regression of subcontractor oversight and real estate construction projects cost overruns

\begin{tabular}{lllllll}
\hline \multirow{2}{*}{ Coefficients Model } & \multicolumn{2}{l}{ Unstandardized Coefficients } & Standardized Coefficients & & \multirow{2}{*}{ Sig. } \\
\cline { 2 - 5 } & B & Std. Error & Beta & & \\
\hline 1 & (Constant) & 37.134 & 1.932 & & 19.220 & 0.000 \\
& Subcontractor oversight & 0.153 & 0.044 & 0.187 & 3.482 & 0.001 \\
\hline
\end{tabular}

a. Dependent Variable: real estate construction projects cost overruns

The simple linear regression coefficients result indicated that there was significant influence of Subcontractor oversight on real estate construction projects cost overruns. The coefficient of the constant term $(\beta 0=37.134$; Pvalue $=0.000<0.05)$ and Subcontractor oversight $(\beta 2=0.153$; P-value $=0.001<0.05)$ were statistically significant. The regression model for Contracting Process was $\mathrm{y}=37.134+0.153 \mathrm{X} 2$ implying that for each unit of Subcontractor oversight, real estate construction projects cost overruns marginally changed by 0.153 units other predictors held constant. It was therefore concluded that Subcontractor oversight and real estate construction projects cost overruns were positively and linearly related. The results are consistent with the findings of a study by Stevens, Frame and Henjewele (2015) who found out that Subcontractor oversight and Real estate construction projects cost overruns were positively and linearly related.

\section{Conclusions and Recommendations}

The research objective was to examine the extent to which Subcontractor Oversight influence Real estate construction projects cost overruns. The simple linear regression coefficients as well as the Pearson correlation results indicated that there was significant influence of Subcontractor Oversight on Real estate construction projects cost overruns. The small p-values; implied that there was a significant influence of Subcontractor Oversight on Real estate construction projects cost overruns.

Considering the study findings and conclusions, the following recommendations were made: Project professionals and other relevant real estate project stakeholders should encourage comprehensive Subcontractor Oversight as critical concerns in assembling pertinent information and creating avenues that could be utilized to reduce real estate construction projects cost overruns. 


\section{Limitations of the Study}

The study involved project professionals in interviews, these are busy people and therefore adequate time was required to schedule meetings with them. The challenge was mitigated through allocating sufficient time for appointments and increased use of online technology for both communication and data collection. The period when the current study was envisioned to take place was marred with great uncertainty of events due to corona virus pandemic but this was mitigated through flexibility of adapting the most effective and functional technology that was used to reach the current respondents.

\section{References}

Ahady, S., Gupta, S., \& Malik, R. K. (2017). A critical review of the causes of cost overrun in construction industries of developing countries. International Research Journal of Engineering and Technology, 4(3), $2550-2558$

Alias, Z., Zawawi, E. M. A., Yusof, K., \& Aris, N. M. (2014). Determining critical success factors of project management practice: A conceptual framework. Procedia: Social and Behavioral Sciences, 153, 61-69. https://doi.org/10.1016/j.sbspro.2014.10.041

Baloyi, L., \& Bekker, M. (2011). "Causes of Construction Cost and Time Overruns": The 2010 FIFA World Cup Stadia in SA. Acta Structilia, 18, 51-67.

Brooke, J. (2013). SUS-A quick and dirty usability scale (in Usability Evaluation in Industry). London publisher

Cantarelli, C., Flyvbjerg, B., Molin, E. J. E., \& van Wee, B. (2010). Cost Overruns in Large-Scale Transportation Infrastructure Projects: Explanations and their Theoretical Embeddedness. European Journal of Transport and Infrastructure Research, 10(1), 5-18.

Chen, X., Ding, Y., Cory, C. A., Hu, Y., Wu, K.-J., \& Feng, X. (2019). A decision support model for subcontractor selection using a hybrid approach of QFD and AHP-improved grey correlation analysis. Eng., Constr. Archit. Manage. https://doi.org/10.1108/ECAM-12-2019-0715.

Cunningham, T. (2017). "Cost Control During the Pre-Contract Stage of a Building Project" - An Introduction, Arrow, Dublin Institute of Technology. Retrieved from http://arrow.dit.ie/beschreoth/49/

de Vaus, D. (2001). Research Design in Social Research. London: SAGE Publications Ltd.

Doloi, H. (2012). Analyzing Factors Affecting Delays in Indian Construction Projects. International Journal Project Management, 30(4), 479-489. https://doi.org/10.1016/j.ijproman.2011.10.004

Doloi, H. (2013). Cost Overruns and Failure in Project Management: Understanding the Roles of Key Stakeholders in Construction Projects. Journal of Construction Engineering and Management, 139, 267-79. https://doi.org/10.1061/(ASCE)CO.1943-7862.0000621

Dow, Sertesilisik \& Ross. (2009). An investigation on the cost implications of methodology of sub-contract work pricing. https://doi.org/10.1108/13664380910977583

Durdyev, S., Omarov, M., \& Ismail, S. (2017). SWOT Analysis of the Cambodian construction industry within the ASEAN economic community, Proceedings of the 28th International Business Information Management Association Conference, Seville, November 9-10.

Enshassi, A., Arain, F., \& Tayeh, B. (2012). Major causes of problems between contractors and subcontractors in the Gaza Strip. Journal of Financial Management of Property and Construction, 17. https://doi.org/10.1108/13664381211211064

Eriksson, P. E., Dickinson, M., \& Khalfan, M. (2007). The influence of partnering and procurement on subcontractor involvement and innovation facilities, 25(5/6), 203-214. https://doi.org/10.1108/02632770710742174

Ershadi, M., Jefferies, M., Davis, P., \& Mojtahedi, M. (2020). Towards successful establishment of a project portfolio management system: business process management approach, 8. 22-41.

Evjen, S., Gunnerud, G., Søfting, R., Lædre, O., \& Lohne, J. (2019). Project Managers: Gatekeepers or Inside Men? https://doi.org/10.1108/S2516-285320190000002057

Havenvid, I., Holmen, E., Linné, Å., \& Pedersen, A. C. (2016). Creating relationship continuity across projects in the construction industry: Deliberate, emergent and deliberately emergent strategies. IMP Journal, 11. https://doi.org/10.1108/IMP-07-2016-0015 
Hewavitharana, T., \& Perera, A. A. D. A. J. (2019). Gap Analysis between ERP procedures and Construction procedures. MATEC Web of Conferences. 266. 03011. https://doi.org/10.1051/matecconf/201926603011

Hwang \& Ng. (2013). Critical Success Factors for Key Players and Objectives: Case Study of Singapore. Journal of Construction Engineering and Management, 139(2), 204-215. https://doi.org/10.1061/(ASCE)CO.19437862.0000597

Jalali, A., Hidzir, N., Jaafa, M., \& Dahalan, N. (2017). An Exploratory Study on the Relationship between the Personal Factors of the Perpetrator and Workplace Bullying. Journal Pengurusan, 49, 67-76. https://doi.org/10.17576/pengurusan-2017-49-06

Khodeir \& Ghandour. (2018). Examining the Role of Value Management in Controlling Cost Overrun (Application on Residential Construction Projects in Egypt). https://doi.org/10.1016/j.asej.2018.11.008

Kothari, C. R. (2004). Research Methodology-Methods and Techniques (2nd ed.). New age international publisher. Kotval and Mullin.

Krejcie, R. V., \& Morgan, D. W. (1970). Determining Sample Size for Research Activities. Educational and Psychological Measurement, 30, 607-610. https://doi.org/10.1177/001316447003000308

Lerner, A. P. (1968). "Microeconomic Theory", Printed in Perspectives in Economics, edited by Brown, Neuberger and Palmatier (Preliminary edition), p. 30.

Lind \& Brunes, F. (2015). Explaining Cost Overruns in Infrastructure Projects: A New Framework with Applications to Sweden. Construction Management Economics, 33(7), 554-568. https://doi.org/10.1080/01446193.2015.1064983

Loosemore. (2013). Innovation, Strategy and Risk in Construction Turning Serendipity into Capability. https://doi.org/10.4324/9780203809150

Mugenda, O. M., \& Mugenda, A. G. (2003). Research methods: Quantitative and qualitative Approaches. Nairobi: African Centre for Technology Studies.

Mwenda, M., Otieno-Omutoko, L., \& Gakuu, C. (2018). Laying an Ethical Foundation in Project Contract Negotiation Process: A Case of the Building Industry in Nairobi, Kenya.

Niazi, G. A. \& Painting N. (2017). Significant Factors Causing Cost Overruns in the Construction Industry in Afghanistan. Procedia Engineering, 182, 510. https://doi.org/10.1016/j.proeng.2017.03.145

Omemo, B. K., \& Sang, P. (2018). Project Management and Performance of Public Sector Construction Projects: A Case of Constituency Development Funds Projects in Migori East, Kenya. International Journal of Current Aspects in Project Management (IJCAPM), 1(I), 13-26.

Rosenfed. (2013). Root-Cause Analysis of Construction- Cost Overruns. Journal of Construction Engineering and Management, 10(1), 1-10. https://doi.org/10.1061/(ASCE)CO.1943-7862.0000789

Sarshar, M., Haigh, R., \& Amaratunga, D. (2004). Improving project processes: best practice case study. Construction Innovation, 4(2), 69-82. https://doi.org/10.1108/14714170410815015

Stevens, J., Frame, I., \& Henjewele, C. (2015). Mediation in construction disputes in England. International Journal of Law in the Built Environment, 8, 123-136. https://doi.org/10.1108/IJLBE-02-2015-0004

The Government of West Australia. (2019). Western Australian government publications, including annual reports, corporate and independent reports, public policy, regulations, standards, guidance, research and analysis.

Zhang, Y., Chen, Y., \& Lu, W. (2021). Contractual and relational enforcement in the aftermath of contract violations: the role of contracts and trust. International Journal of Managing Projects in Business. https://doi.org/10.1108/IJMPB-06-2020-0202

\section{Copyrights}

Copyright for this article is retained by the author(s), with first publication rights granted to the journal.

This is an open-access article distributed under the terms and conditions of the Creative Commons Attribution license (http://creativecommons.org/licenses/by/4.0/). 